Forthcoming in Capital \& Class 2014

\title{
GRAMSCI AND THE POLITICS OF EDUCATION
}

This paper deals with aspects of Antonio Gramsci's thinking on education and related cultural work, highlighting issues such as those of effective curricula, different forms of educators/intellectuals, work-oriented education and popular education which have resonance with contemporary debates in the field. Gramsci's ideas provide insights for an effective contemporary socialist pedagogical politics that are based on the principle of critical access to 'powerful knowledge' and experiences that promote critical thinking, in formal educational institutions and other learning settings.

It would not be amiss to argue that Gramsci stands out among Marxist writers who have written on or whose ideas are relevant to education and culture. He has written directly and systematically on aspects of education. In the case of schooling, he has furnished us with notes that have the length of almost fully developed essays (see Q, $1 \mathrm{~V}$ and XII). ${ }^{i}$ But he has furnished us with many more insights on the educational basis of power than are contained in these notes. Gramsci's entire project surrounding the all pervasive concept of hegemony, which runs through the Quaderni (Gramsci, 1975), is an educational project. To discuss Gramsci's contribution to the development of the fields of education and culture one must therefore scour the entire corpus of his works (Borg, Buttigieg and Mayo, 2002: 3). In Gramsci’s own words, "Every relationship of 'hegemony' is necessarily an educational relationship and occurs not only within a nation, between the various forces of which the nation is composed, but in the international and worldwide field, between complexes of national and continental civilisations.” (Gramsci, 1971: 666) In short, to miss the educational element (education is here conceived of in its widest context and not limited to formal institutions) embedded in relations of hegemony is to overlook the central core of hegemony and therefore a crucial aspect of Gramsci's conception of power and the quest for social and political transformation. Education, viewed in its all-encompassing manner, is 
central to the workings of hegemony (Borg, Buttigieg and Mayo, 2002). People attempting to understand Gramsci's political theory avoid this dimension at their peril.

\section{Intellectuals and the organization of culture}

It would be reductionist therefore to confine one's analysis of education to the long notes on the 'Unitarian School'( Baldacchino , 2002). I will show that the particular view presented by Gramsci here is most relevant today and is being reinforced in the contemporary curriculum literature. It is equally reductionist to confine oneself to these and other pre-prison and prison writings and letters on various aspects of learning in childhood and with adults, including letters concerning the education of his children and niece Edmea (Borg, Buttigieg and Mayo, 2002: 3, 4), important though these writings are in terms of providing insight into his educational thinking. It would be equally limiting to focus just on these and the factory council theory with its most valuable insights for adult education for industrial democracy, insights still relevant today (Livingstone, 2002). These are all key works and need to be read and reread, since they provide signposts for a critically engaged education. However they have to be analysed within the broader all encompassing context for education which is the bulk of Gramsci's oeuvre.

\section{Broadening the Educators' Profile}

In this regard, Gramsci also broadens the notion of the educator or educators. He refers to professional school teachers, including those who taught him in his schools, as exemplified in his letters from prison (see Borg, Buttigieg and Mayo, p. 4). He holds some of those who taught him at the liceo responsible, through their mediocre teaching, for making him move away from the "exact sciences" and Mathematics, for which he had a predilection as a boy; he ended up choosing Greek over Maths when given the choice. (Ibid.) He also refers to his ventures into the broader domains of education and not only in an organized sense, but also non-formally or 
informally. He himself was educator and student at a prison school on the 'prison island' of Ustica, awaiting his trial with others, an experience which is said to have left a mark on the history of education on the island itself; the school was open to everyone including the inhabitants.

His conception of the educator is however broad enough to comprise a variety of practitioners, some of whom might not immediately identify themselves as such. His notion of the educator includes party activists working in the field of workers' education, something he himself engaged in even during his early political career. It would include foremen or supervisors in the context of the Factory councils, as conceived of by him in his writings on industrial democracy. It can include people of different technical and cultural backgrounds being invited as speakers to the Ordine Nuovo group (the group surrounding the periodical of socialist culture) or who collaborated at the Club Vita Morale. It can also include any intellectual, whether publically visible or not, either those we today call 'public intellectuals,' or those considered subaltern intellectuals ${ }^{\mathrm{ii}}$. They would serve as opinion leaders and promoters of particular conceptions of the world through their affirmations, strictures and actions. These fall within the range of Gramsci's broad strata of organic intellectuals, who either support the existing state of affairs and hegemonic bloc (agrarian bloc in the case of the Mezzogiorno) or challenge or renegotiate the relations which keep this set of hegemonic arrangements in place.

Gramsci's conception of the educator can also include so-called 'traditional intellectuals' whose organic purpose seems over since they are residual specimens of an earlier and possibly outdated hegemonic set of arrangements and therefore assume the appearance of a 'neutral' category, identified by their immanent features, when in effect they can well serve to maintain and legitimize the status quo. They might also lure potentially progressive intellectuals from their 
immediate cultural context with a status and language that renders them alien to that very same terrain. Ives (2004) has discussed this with respect to intellectuals and language development. These intellectuals absolutize their activity. Organic intellectuals had an important role to play in elaborating and creating connections between the spontaneous grammars (regional languages and dialects) of the popular classes. This was not happening in Gramsci's time. People who would have otherwise provided intellectual leadership among the subaltern classes were being co-opted partly through their being equipped with a normative grammar (various forms of standard language, including esoteric language) that was alien to the subordinated classes. It therefore served to alienate potential organic intellectuals from these classes rendering them traditional intellectuals instead - intellectuals whose activity deceptively appeared to be devoid of any social moorings when in actual fact this activity served to consolidate the hegemony of the dominant groups. iii

This broad notion of educators and, to use a term which is very much in vogue at present, 'cultural workers,' is something which has had an impact on the manner in which educational and cultural activity are being viewed today in progressive sections of the literature on education and culture in the Anglo-American influenced world. The work of Henry A. Giroux and his notion of 'public pedagogy' (Giroux, 1999) come to mind here.

The 'public pedagogy' concept best captures Giroux's attempt to extend the notion of education well beyond the important though very limited context of schooling, bearing in mind, once again, Gramsci's dictum that every relationship of hegemony is an educational relationship. In this respect, Giroux, one of the founding figures of what is called 'critical pedagogy,' (Giroux, 2011) scours a broad terrain in his educational and cultural writings, comprising a variety of pedagogical sites that extend beyond the system of formal education. For Giroux, therefore, 
educational activity is engaged in by not only professional teachers and academics but a broader array of cultural workers that includes journalists and op-ed columnists, community activists and animators, architects, advertisers, photographers, artists, actors, film directors, social activists, religious ministers, musicians and so forth. This partly explains why Giroux gradually moved from writing mainly about public schooling to engaging in lengthy discussions of broader social issues, such as war and corporate power, and various forms of cultural production such as film, cartoons and media news packages. This represents a marked contrast with Giroux's early work around schooling. Gramsci's impact on current progressive and leftist thinking on education and culture is nowhere more clearly represented than in Giroux’s work. (Mayo, 2012)

\section{Education and the State}

Education in its broader context is, for Gramsci, an essential feature of the 'ethical state', the state as educator if you will. The state and its institutions have a strong educational dimension. The separation between the state and civil society, as well as the separation between civil and political society, in Gramsci's work, is done for purely heuristic purposes. As underlined by Thomas (2009), they are much more integrated than such a heuristic separation would have us believe, hence Gramsci's reference to the integral state. The same applies to the separation between the ideological/consensual and the repressive, in short force and consent, the twin heads of Macchiavelli's Centaur. All this has implications for the field of education where the lines between these facets of the same state are blurred. Althusser (1971) had himself warned

of there being no such thing as a 100\% ideological state apparatus (ISA) or 100\% repressive state apparatus (RSA). Educational institutions comprise elements of both. One has only to observe documentation attesting to the use of security guards within public schools and reports 
concerning their alleged use of heavy handed methods with pupils (Giroux, 2009) to highlight the dual aspect of these public educational institutions. I would argue that, apart from the obvious repressive element here, there is also a symbolic element in the violence perpetrated. It signals to the students something about their identities, perhaps that of potential criminals who could eventually be incarcerated, a signal that is very much in keeping with the function of an ISA (Mayo, 2011; English and Mayo, 2012). ${ }^{\text {iv }}$ Other manifestations include student expulsions from school, staff dismissals, black-listings, non-promotions, non-tenure, harassment of teacher union activists, and, to provide an example from contemporary Turkey, harassment of secular and leftist teachers. ${ }^{\mathrm{V}}$

Education and cultural formation in their various forms play a strong part in the process of ideological work that prefigures the transformation of the state which is only complete when control over the state apparatus is achieved thus ensuring control over the process of exchange etc. As Gramsci maintains, "class consciousness cannot be completely modified until the mode of life of the class itself is modified, which entails that the proletariat has become the ruling class" (Larrain, 1983: 82) through "possession of the apparatus of production and exchange and state power" (my translation from Gramsci’s tract, 'Necessita` di Una Preparazione Ideologica di Massa', Gramsci, 1997: 161).

Furthermore different countries are at different levels in terms of the relationship between state, political and civil society. While some countries may be well advanced in the transformation of civil society prior to the conquest of the state, others still have to build and transform most of civil society following the conquest itself. Peter Thomas (2009) underlines this, arguing that it applies to both east and west and north and south. 
This has implications for the manner of conceptualization of the nation state in the process of the intensification of globalization. Globalization has been a characteristic of the capitalist mode of production from its inception as indicated by Marx and Engels in the 1848 Manifesto:

The need of a constantly expanding market for its products chases the bourgeoisie over the whole surface of the globe. It must nestle everywhere, settle everywhere, establish connections everywhere. The bourgeoisie has through its exploitation of the worldmarket given a cosmopolitan character to production and consumption in every country. To the great chagrin of reactionists, it has drawn from under the feet of industry the national ground on which it stood. (Marx and Engels, 1848/1998: 7-8)

The terrain of operation widens in this context. The nation-state, however, remains central to this process of hegemonic globalization, in Bonaventura de Sousa Santos' terms (in Dale and Robertson, 2005), meaning 'globalization from above'. The state does not wither away. As Ellen Meiskins Wood (2003: 5-6) has argued:

The argument here is not that of capital in conditions of "globalization" has escaped the control of the state and made the territorial state increasingly irrelevant. On the contrary, my argument is that the state is more essential than ever to capital, even, or especially, in its global form. The political form of globalization is not a global state but a system of multiple states, and the new imperialism takes its specific shape from the complex and contradictory relationship between capital's expansive economic power and the more limited reach of the extra-economic force that sustains it.

The state is alive, has a material presence and, as always, is constituted by social relations, even if it now has the function of developing and activating the infrastructure for the mobility of capital, training the potential labour force (the so-called 'human resources') and also engaging in economic activity. It sustains the private sector with a series of incentives and enters the commercial terrain, blurring the boundaries between public and private as in the case of higher education. In addition, it also assumes the character of what Giroux and others have called the carceral state. It adopts repressive measures in public spaces like schools in the USA, and imprisons. It disciplines those who suffer and fall by the wayside as a result of neoliberal 
policies (the imprisonment of a substantial number of Afro-American and Hispanic youth in the USA). In addition, in certain countries, including frontier European islands in the Mediterranean (e.g. Malta and Lampedusa), it incarcerates, in detention centres, numerous immigrants who flee from misery in their colonially and neo-colonially ransacked home countries and continents. These are all manifestations of the carceral state.

It is against this backdrop and the nature of relations between state and civil society, force and consent, in the Gramscian sense, that education in its various manifestations needs to be seen. This has implications for the situation, under Neoliberalism, when the social contract, that renders education a public good, is undermined as the bulk of spending shifts towards the private sector and the military-industrial complex, with provision becoming a consumer good instead. There are those who are denied citizenship in this scenario, especially the undocumented immigrants (Pisani, 2012), which automatically leaves them out of the social contract. Many are those, on the other hand, who get a raw deal from this contract as they are fobbed off with an underfunded and often vilified and despised public service, in many countries. This lends a specific meaning to the term 'subaltern' in this day and age. This applies to the quality of 'free'

state/public schools in many contexts (e.g. inner city schools in the USA), although we still have countries such as Chile where even state schools are fee paying.

\section{Curriculum and learning}

Against this scenario, the struggle for education as entitlement and as a public good becomes an important one for those clinging to a socialist perspective. Gramsci's insights of more than seventy five years ago have been gaining greater resonance in recent times. Here I must perforce refer to the writings on the Unitarian School since they are gradually becoming a 
very important source of reference once again. In Mario Alighiero Manacorda’s words (in Gramsci, 1972: xxix), they are a sort of epitaph for the old classical school which cannot continue to be any longer as times have changed. And yet Gramsci felt that it was being replaced, in his time, by a more retrograde one, as introduced by the Riforma Gentile, the reform of public education which takes its name from the Minister of Public Instruction during the Fascist period, the idealist philosopher Giovanni Gentile, who introduced it. ${ }^{\text {vi }}$ Gramsci's notes on his envisaged type of school place the emphasis on content and learning, in addition to process. Rigour is, for Gramsci, paramount if students from subaltern groups are to acquire the kind of powerful knowledge that does not confine them to the margins of economic and political life. His writings that extol the virtues of the classical school, which, among other things, provided for the study of Latin and Greek, point to this. He felt that these two areas (Latin and Greek), as is the old school, need to be replaced but he also warns that the search for a new area that conveys the same type of psycho-physical habits and intellectual discipline, including the ability to engage in systematic and logical thinking (skills which need to be learnt), will be an arduous one.

The main concern, echoed among contemporaries, is that hybridization of curricula often results in a watered down version of that kind of knowledge which for years has been the preserve of the ruling classes. They obtain this knowledge and pass it on to their offspring not only through the exclusiveness of elite schools but also through their cultural milieu that is very much in tune with the demands of this type of intellectual formation. Working class children and members of other subaltern groups, such as certain ethnic minorities, do not enjoy the privilege of acquiring this knowledge from sources outside the school, through what are currently being called 'invisible pedagogies'. 
In watering down curricula on the pretext that it renders them closer to life, one is probably shortchanging these children, denying them mastery of certain areas which have stood the test of time and proved crucial in terms of economic and political success. Like another Italian educator, Lorenzo Milani, who believed that the change should occur in the manner of the way things are taught and schooling is organized, including longer hours to make up for the cultural capital divide (Milani, 1988, p. 54; Milani, 1991, p.31), Gramsci also sought to bridge this divide by virtue of conceiving of a boarding school. This was to have an active component in later years, indicating Gramsci's belief in a participatory and collective kind of education (where education is interactive and older students help the younger ones in a form of peer tutoring) but which still placed the emphasis on mastering what, for want of a better term, would be called 'powerful knowledge'.

Gramsci saw access to this knowledge for working and peasant class children being severely threatened by the form of 'educativity' brought about by what he regarded as the Fascist dilution of Dewey's progressive and pragmatic ideas. This type of educational policy allowed more meaningful participation to those who acquired the resources and cultural baggage for this purpose from elsewhere - their surrounding and materially rewarding cultural milieu. Furthermore there was an attempt to curtail the provision of a holistic education by channelling students into vocational schools (professional schools) which would mortgage their future (“ipotechi l'avvenire del fanciullo"- Gramsci, in Manacorda, 1970, p. 32). This early vocational track could well have been seen as providing the initial steps towards the creation of the Fordist 'trained gorilla' (gorilla ammaestrato) (Gramsci, 1971, p. 139) It would have continued to subvert the kind of decent and empowering education which Gramsci saw appropriate for every child, especially children belonging to the subaltern strata of society. 
Michael Young and Johan Muller (2010) are among two contemporary curriculum specialists who have been arguing along similar lines, having critiqued different forms of progressive discourses on education for pointing or gesturing towards what can easily turn out to be a watered down version of education for those who do not obtain the benefits (see Young, 2004), from elsewhere, of 'invisible pedagogies.' Excessive emphasis on hybridization as opposed to strong classification (in Basil Bernstein's terms) of certain areas of knowledge can lead to superficiality and denial of access to the kind of knowledge that really matters in the real world characterized by specific power configurations. They argue for a future curriculum scenario, called Future 3 (Future I is characterized by strong classification, sharp disciplinary boundaries while Future 2 is characterized by loose classification and hybridization). Future 3 is characterized by "Boundary maintenance as prior to boundary crossing. In this 'Future' it is the variable relation between the two that is the condition for the creation and acquisition of new knowledge." (Young and Muller, 2010: 16) This scenario allows for some flexibility in the broadening of and crossing boundaries but retains some fixed ones around key disciplines that constitute 'powerful knowledge'. 'Powerful knowledge,' for Gramsci, also included language. Gramsci was, for instance, adamant that peasants had to learn a standard language, despite its political imposition, to transcend their insular environment characterised by campanilismo (parochialism) (Gramsci, 1964: 236). ${ }^{\text {vii }}$

If it is true that every language contains the elements of a conception of the world and of a culture, it could also be true that from anyone's language, one can assess the greater or lesser complexity of his (sic) conception of the world. Someone who only speaks dialect, or understands the standard language incompletely, necessarily has an intuition of the world which is more or less limited and provincial (Gramsci, 1971: 325)

Young and Muller argue that "access to powerful knowledge is a right for all not just the few, with a theory of 'powerful knowledge' and how it is acquired and the crucial role of formal 
education in that process." (Young and Muller, 2010: 24) Their position is as tentative as Gramsci's in his notes on the Unitarian school. In fact they strike a parallel between their approach towards Futures 2, a reaction to Futures 1, and Gramsci's feelings towards the Rousseau-inspired approach and that of traditional 'top down' schooling. They end their 2010 paper by quoting the famous statement by Gramsci in the relevant prison notes to the effect that the active school is still in its romantic phase as it serves as a logical and radical alternative to the mechanistic Jesuitical school and which must eventually enter the classical phase (Gramsci, 1971:32-33), classical conceived of in terms of rationalization and balance. In presenting what they call Futures 3, Young and Muller argue for an attempt at a rational balance.

As for vocationalisation, Gramsci's factory council theory, with its emphasis on workers acquiring a broader and total conception of the production process, to combat, among other things, the threat of alienation, arising from being only a partial operation in the system, serves as an antidote to the current educational discourse. This includes the lifelong learning discourse concerning 'employability'. The emphasis here is not on 'learning to earn' or 'learning for work' but on learning to engage critically with work. This approach has been highlighted in critical education circles in more recent times (e.g. Simon, Dippo and Schenke, 1991).

Engaging critically with work emerges clearly in Gramsci's writings that are of relevance to adult education. It is here, in adult education as an important component of lifelong learning, where the contemporary hegemonic discourse of 'employability' prevails, not least in the relevant memorandum and other communications from the European Union(CEC, 2000). The Factory Council Theory, which Gramsci juxtaposed against the vision of trade unionism of his time, with its image of the worker as simply wage earner bargaining within the given framework, was intended to bring about a transformation in the nature of workers' organization and 
education. In Gramsci's earlier writings on the issue, the councils were conceived of as an alternative to Unions. (Gramsci, 1977: 76) After the failure of the revolution (occupation of the factories), Gramsci began to present the factory councils as the vehicle for transforming trade unions, as both were to work in tandem (Gramsci, 1978: 21). Engaging critically with work meant learning according to a broader vision of social relations, the basis of a different state, a workers' state (Gramsci, 1977: 66). It entailed operating in a manner that was in keeping with an alternative and broader economic and social vision, one which transcended the capitalist wage relation and therefore capitalist social relations in general. This is an antidote to the current widespread hegemonic situation and discourse, concerning HRD and other labour market training. The discourse is that of learning to work within the given Capitalist framework.

One important aspect of Gramsci's work, which resonates with a modern day critical approach to education, is that of teaching against the grain (Simon, 1992). It is precisely in the reading of Italian history that Gramsci provides some useful insights in this regard. His reading of Italian history, and specifically the Risorgimento, with its implications for the study and teaching of the subject, was a revelation to the present writer. This writer was exposed to a very conventional standard and sanitized account of the nature of the Italian 'unification' in his schooling years as prescribed by syllabuses for a UK based examination (GCE O level). Gramsci's exposure of the process of 'internal colonization' that occurred in Italy through the Risorgimento is instructive in terms of engaging with history critically and highlighting 'subjugated' areas of information and knowledge, as Foucault would say. This approach once again approximates Gramscian work on the subject to that of Italy's leading critical educator, don Lorenzo Milani at the school of Barbiana. Milani and his students also read history against the grain and echo Gramsci in their exposure of the role of the ruling Northern bourgeoisie in the 
rise of fascism and the process of colonial expansion not only internally (Italy represents a case of 'internal colonialism' involving North and South) but also externally. These approaches acquired greater critical resonance in 2010 , the year that marked the 150 anniversary of the socalled 'Italian Unification.' This was evident in such works as those by Pino Aprile (2010, 2011) who arguably provides an even more damning account than Gramsci's regarding the brutal process of Piedmontese colonization that took place and the massacres in the South it brought about. This reading bears affinities with Gramsci's own account in terms of debunking myths concerning Italian history. It provides a key signpost for a critical engagement with events that underline the complexity and different levels of colonial relations, including internal ones (that is within the same nation state).

The debunking of such myths connects with one other major area of inquiry in Gramsci proposed work für ewig (for eternity). ${ }^{\text {viii }}$ A rigorous education in schools and various sites of learning, including adult learning, entails systematic investigation of different social structures and constructions of reality, as captured in Gramsci's notes on the study of philosophy. Like history, philosophy, or rather systematic investigation and inquiry, serves as the tool to transform 'common sense,' not to be conceived in terms of simply 'false consciousness,' into good sense. Common sense is a fragmented and contradictory form of consciousness, which has its valid elements since it connects with people's quotidian experience.

Common sense is, according to Gramsci, a "philosophy of non philosophers" (Gramsci, 1975:1396), a worldview uncritically accepted within the various social and cultural environments that help develop a person's moral individuality (Ibid; Borg and Mayo, 2002: 90). Gramsci links it with popular religion and 'folklore', the latter consisting of beliefs, values and norms that are uncritical, contradictory and ambiguous (Borg and Mayo, 2002:91). Through the 
'philosophy of praxis', this common sense can be superseded in that it would be accorded the sort of elaboration experienced by Lutheranism and Calvinism (they, according to Gramsci, represent the last great process of 'intellectual and moral reform' witnessed in Europe). It would, as a result, develop into a "superior culture" (Caruso, 1997: 85, 86) or civiltá.

The task is to render it coherent. The implication for effective teaching to be derived from this is that, as with Paulo Freire's (1970) 'pedagogy of praxis', so close in terminology to Gramsci's overarching 'philosophy of praxis,' educators and learners need to start from their existential situation. They then engage critically through praxis, the obtaining of critical distance, to uncover the underlying contradictions of one's reading of the world, history, specific situations etc. This can help a person develop a more coherent and therefore critical view of things.

\section{Conclusion}

The Gramscian influence on education has affected not only people ensconced in academies but also, and rightly so, those who operate at the grassroots, including the many popular educators engaged in non formal education in Latin America (Gramsci is very influential in this part of the world - La Belle, 1986, Aricó, 1988, Torres, 1990, Morrow and Torres, 1995; Kane, 2001, Mariátegui, 2011) and elsewhere (Latin American influences have been taken up in other geographical contexts. E.g. The Jesuit Centre in Toronto, Canada). Popular education has proven palatable to people clamouring for better education at the World Social Forum or operating in non formal and informal education within the contexts of community action and development and social movements. A number of works, notably by Margaret Ledwith in community development (Ledwith, 2011) and Budd Hall et al (2012) with social movements, bridge the different domains, those of popular education, social movements and community 
activism. Gramsci's ideas feature prominently in all three not only because of his direct influence on popular education but also because of his being a highly influential figure for education in his own right.

His emphasis on rigour and the inculcation of self discipline, as well as the acquisition of powerful knowledge, which includes established knowledge such as the standard language, will hopefully ensure that those engaged in these projects will keep their feet firmly on the ground in their attempt to effectively bridge the cultural power divide. On the other hand, and this is key, Gramsci was under no illusion regarding the ideological bases of this knowledge. So, for instance, while he harped on needing to learn the standard language not to remain at the periphery of political life, he constantly demonstrated that the established Italian language was imposed in a form of 'passive revolution' (not rooted in popular consciousness). He indicated that there was work to be carried out to create a 'national popular language' born out of a synthesis of all other 'spontaneous grammars' - quite a tall order in my view. The inference to be drawn is that one must underscore, in the educational process, the ideological basis of language. This entails helping the learner become aware of the political ramifications of this choice of language. The same would hold for other forms of powerful knowledge. Simply reproducing the dominant forms of knowledge as if they were a given would be anathema for any form of critical education. And there is evidence to suggest, from Gramsci's own writings, even on the Unitarian School, that Gramsci was averse to uncritically reproducing the dominant 'cultural arbitrary' (preferences), to use Bourdieu's term. He refers to the teacher who simply dishes out facts as 'mediocre' (Gramsci, 1971: 36) and writes that subjects such as Latin have to be replaced (Gramsci, 1971: 39, 40) because times have changed. Furthermore, his general discussions concerning artistic expression and different forms of cultural production place the emphasis on 
the exploration of the revolutionary potential of 'new' emerging or hitherto repressed forms of culture and at the same time on critical appropriation of dominant forms of culture. The language example remains illustrative of his attitude towards dominant forms of cultures that have to be learnt. In a country with a strong colonial past, such as the one in which I have been born and bred, learning English is a must if one is to avoid remaining on the margins. But the genuine political approach to this, along Gramscian and Freirean lines, would be to teach the language in a manner that entails providing awareness of its ideological underpinnings and the role it plays in the process of social stratification. It also means giving equal importance to the subaltern national-popular language (Maltese) without playing off one language against the other. It is this aspect of Gramsci's work which renders it an appropriate complement to the more ostensibly 'emancipatory' one of Paulo Freire, something which I underlined elsewhere in a full length book study and book chapter (Mayo, 1999; Mayo, 2005/2008). Gramsci is calling for a more classical balance between the ideals of what he calls the Rousseau school (he discussed this issue in letters to family members) and the old classical school. His ideas serve as a warning to critical educators. They are to avoid the sort of overzealous approach that can lead them to throw out the baby with the bathwater. Their quest for an ostensibly 'emancipatory' education might well result in having the contrary effect, that of disempowering students.

\section{References}

Aprile, P. (2010). Terroni. Tutto quello che è stato fatto perche gli Italiani del Sud diventassero Meridionali (People who work the land. All that was made for Italians from the South to become Southerners). Milan: Piemme.

Aprile, P (2011) Giu al Sud. Perche I Terroni salveranno l'Italia (Down South. Why the People who work the Land will save Italy), Milan: Piemme.

Aricó, J. (1988). La Cola del Diablo. Itinerario de Gramsci en America Latina (The Devil's Tail. Gramsci’s Itinerary in Latin America). Caracas: Editorial Nueva Sociedad. 
Althusser, L (1971) Lenin and Philosophy and Other Essays, New York \& London: Monthly Review Press.

Baldacchino, J (2002) On a dog "chasing its tail" Gramsci's Challenge to the Sociology of Knowledge. In Borg, C, Buttigieg, J. A and Mayo, P. (eds.), Gramsci and Education, Lanham, Maryland: Rowman \& Littlefield

Borg, C, Buttigieg, J and Mayo, P (2002), Introduction. Gramsci and Education. A Holistic Approach. In Borg, C, Buttigieg, J. A and Mayo, P. (Eds.), Gramsci and Education, Lanham, Maryland: Rowman \& Littlefield.

Borg, C and Mayo, P. (2002), Gramsci and the Unitarian School. Paradoxes and Possibilities. In Borg, C, Buttigieg, J and Mayo, P. (Eds.), Gramsci and Education, Lanham, Rowman \& Littlefield.

Caruso, S (1977) La riforma intelletuale e morale'(The Intellectual and Moral Reform). In Mastellone, S (ed.), Gramsci: I Quaderni del Carcere. Una riflessione politica incompiuta (Gramsci: The Prison Notebooks. An Incomplete Political Reflection), Turin: UTET Libreria.

CEC (2000), Commission Staff Working Paper. A Memorandum on Lifelong Learning, Brussels: European Commission.

Dale, R., and Robertson, S. (2004). Interview with Boaventura de Sousa Santos. Globalization, Societies and Education, 2(2): 147-160.

English, L and Mayo, P (2012), Learning with Adults. A Critical Pedagogical Introduction, Rotterdam and Taipei: Sense Publishers.

Freire, P (1970), Pedagogy of the Oppressed, New York: Continuum

Giroux, H.A (1999), The Mouse that Roared. Disney and the end of Innocence, Lanham: Rowman \& Littlefield.

Giroux, H.A. (2009), Brutalising Kids: Painful Lessons in the Pedagogy of School Violence. Truthout 8/10/2009, http://www.truthout.org/10080912, accessed 13/01/2013.

Giroux, H.A. (2011) On Critical pedagogy, N. York and London: Continuum/Bloomsbury.

Gramsci, A. (1964), 2000 Pagine di Gramsci. (Vol. 1 Nel Tempo della Lotta 1914-1926 ) (2000 Pages by Gramsci. Vol. 1, In the time of Struggle 1914-1926), Ferrara, G. and Gallo, N (eds), Milan: Il Saggiatore.

Gramsci, A., (1971), Selections form the Prison Notebooks, Hoare, Q and Nowell Smith, G (eds.), New York: International Publishers.

Gramsci, A. (1972), L'Alternativa Pedagogica (The Pedagogical Alternative), Manacorda, M.A. (ed.), Firenze: La Nuova Italia. 
Gramsci, A. (1975), Quaderni del Carcere, Edizione Critica (Prison Notebooks. Critical Edition), (IV vols), Gerratana, V. (ed.) Turin: Einaudi.

Gramsci, A. (1977), Antonio Gramsci, Selections from Political writings (1910 - 1920), Hoare, Q and Matthews, J. (eds.), New York: International Publishers.

Gramsci, A. (1978), Selections from Political Writings (1921-1926), Hoare, Q. (ed.), New York: International Publishers.

Gramsci, A. (1996), Lettere dal Carcere 1926 - 1937 (Letters from Prison 1926-1937), Santucci, A. (ed.), Palermo: Sellerio Editore.

Gramsci, A. (1997), Antonio Gramsci, Le Opere. La Prima Antologia di Tutti Gli Scritti (Antonio Gramsci. The Works. Anthology of all the Writings), Santucci, A (ed.), Rome: Editori Riuniti.

Hall, B. L., Clover, D. E., Crowther, J and Scandrett, E. (eds.) (2012). Learning and Education for a Better World: The Role of Social Movements. Rotterdam, Boston, Taipei: Sense Publishers

Ives, P. (2004), Language and Hegemony in Gramsci, London: Pluto Press; Halifax N.S: Fernwood Publishing.

Kane, L (2001) Popular Education in Latin America, London: Latin American Bureau.

La Belle, T. J. (1986). Non formal education in Latin America and the Caribbean-stability, reform or revolution?. New York: Praeger.

Larrain, J (1983), Marxism and Ideology, New Jersey: Humanities Press

Ledwith, M. (2011). Community development. A critical approach. (second edition) Bristol, UK: Policy Press.

Livingstone, D. (2002), Working Class Learning, Cultural Transformation, and Democratic Political Education: Gramsci's Legacy. In Borg, C, Buttigieg, J. A and Mayo, P. (eds.), Gramsci and Education, Lanham, Maryland: Rowman \& Littlefield.

Manacorda, M. A (1970) Il Principio Educativo in Gramsci, Rome: Armando Editore.

Mariátegui, J.C (2011), José Carlos Mariátegui. An Anthology, Vanden, H.E and Becker, M (eds. and trans.), New York: Monthly Review Press.

Marx, K and Engels, F (1848/1998) The Communist Manifesto. New York: Monthly Review Press

Mayo, P. (1999) Gramsci, Freire and Adult Education. Possibilities for Transformative Education, London and New York: Zed Books. 
Mayo, P (2005/2008) Antonio Gramsci and Paulo Freire some connections and contrasts. Encyclopaidea. 17: 77-102; In Torres, C.A and Noguera, P (eds.), Social Justice Education for Teachers Paulo Freire and the Possible Dream, Rotterdam, Boston and Taipei: Sense Publishers.

Mayo, P (2011) The Centrality of the State in Neoliberal Times. Gramsci and Beyond. International Gramsci Journal. 3: 56-70.

Mayo, P (2012) Echoes from Freire for a Critically Engaged Pedagogy, London and New York: Bloomsbury.

Meiksins Wood, E. (1998). The Communist Manifesto.150 years later. In Marx, K and Engels, F, The Communist Manifesto. New York: Monthly Review Press.

Milani, L. (1988) 'Milani's Letter to the Judges' (edited and translated by Burtchaell, J.T.) in Burtchaell, J.T. (Ed.), A Just War no Longer Exists. The Teaching and Trial of Don Lorenzo Milani, Indiana: University of Notre Dame Press.

Milani, L. (1991), L’Obbedienza Non e`Piu`Una Virtu`(Obedience is no longer a virtue), Florence: Libreria Editrice Fiorentina.

Morrow, R.A and Torres, C.A. (1995). Social theory and education. A critique of theories of social and cultural reproduction. Albany: State University of New York Press.

Pisani, M (2012) Addressing the 'Citizenship Assumption' in Critical Pedagogy: exploring the case of rejected female sub-Saharan African asylum seekers in Malta. Power and Education 4(2): $185-195$

Simon, R.I, Dippo, D and Schenke, A (1991), Learning Work. A Critical pedagogy of Work Education, Toronto: OISE Press; New York: Bergin \& Garvey.

Simon, R. I (1992) Teaching against the Grain. Texts for a Pedagogy of Possibility, Toronto: OISE Press; New York: Bergin \& Garvey.

Thomas, P. D (2009), The Gramscian Moment: Philosophy, Hegemony and Marxism, Amsterdam: Brill.

Torres, C.A. (1990). The politics of nonformal education in Latin America. New York: Praeger.

Young, M. (2004) Curriculum Studies and the problem of Knowledge. Updating the Englightenment? In Lauder, H., Brown, P., Dillabough, J.A. and A. H. Halsey (eds.) Education, Globalization and Social Change, Oxford: Oxford University Press.

Young, M and Muller, J (2010), Three Educational Scenarios for the Future: lessons from the sociology of knowledge. European Journal of Education, 45 (1): 11-27.

\section{Notes}


'Some commentators have been misled into believing that Gramsci actually wrote an essay 'on Education', instead of notes on the subject, a misconception fuelled by Quentin Hoare and Nowell Smith's use of this title when editing their selections from the prison notebooks (Gramsci, 1971)

ii The public intellectual is that intellectual whose reach is broad enough to incorporate a large viewership, listenership or readership as a result of appearances on or contributions to community, regional or national broadcasting or print media; today this can be even global through the internet etc. The public intellectual combines theoretical rigor with accessibility and draws upon a variety of scholarly, popular, and interdisciplinary resources to address important social and political issues. Clear examples of public intellectuals nowadays would be Noam Chomsky, the late Howard Zinn, Naomi Klein, the late Edward Said, Carol Becker, the late Pierre Bourdieu, Henry Giroux, Slavoj Zizek, to name but a few. These are intellectuals who cast their nets far and wide. Then there are those subaltern intellectuals like teachers, priests, local community educators etc who restrict their operation to specific sites. Gramsci saw priests, lawyers, notaries, doctors as subaltern traditional intellectuals in comparison with those more public intellectuals (on different sides of the political spectrum) of his time as Giustino Fortunato, Piero Gobetti, Luigi Pirandello, Gaetano Salvemini and Benedetto Croce whose ideas and widely expressed opinions influenced large sections of the population and helped shape Italy's cultural climate at the time.

iii This section owes a lot to the rich discussion on the subject of 'Language and Hegemony in the Prison Notebooks in Ives (200\$) Chapter 3

${ }^{\text {iv }}$ I am very indebted to Professor André Elias Mazawi, from the University of British Columbia, Canada for this point.

${ }^{\mathrm{v}} \mathrm{I}$ am indebted to one of the anonymous reviewers for this point.

${ }^{\mathrm{vi}}$ It consisted in the stratification of schools in terms of gymnasium (five years), technical school (3 years), magisterial schools (preparing elementary school teachers -seven years duration in all) and the professional school (vocational schools). Not all of these schools could lead to enrolment in a university course, and the professional school did not lead to enrolment at any other school. See http://www.pbmstoria.it/unita/scuola/lariformagentile.php Accessed $29^{\text {th }}$ June 2013.

vii Gramsci was under no illusions that this national language, as anything else that was 'national', represented anything but the select interests of a dominant group. Gramsci favoured a process of linguistic hegemony characterised by the presence of a normative grammar that derived from the interactions of the spontaneous grammars found in the different regions of the peninsula - a national popular standard language, if you will, which would be more democratic in that it reflected the 'collective will' (see Ives, 2004: 100).

${ }^{\text {viii }}$ He tells Tania, in a letter, dated 19 March 1927, that he has been tormented by this idea, a "phenomenon" found among prisoners, in keeping with a complex conception of Goethe which greatly preoccupied Pascoli. (Gramsci, 1996: 55). The reference here is to Pascoli's Per Sempre (forever) contained in his Canti del castelvecchio (Santucci, in Gramsci, 1996: 58). 